\title{
SOME OBSERVATIONS ON INDUSTRIAL PUMPS FOR EXTRACORPOREAL CIRCULATION IN MAN
}

\author{
BY \\ J. E. HALL, P. A. JAMES, B. G. B. LUCAS, AND D. J. WATERSTON \\ From the Cardiac Research Unit, The Hospital for Sick Children, Great Ormond Street, London
}

(RECEIVED FOR PUBLICATION NOVEMBER 28, 1957)

Following the introduction by Gibbon (1937) of a practical method of extracorporeal circulation, many other machines have been developed capable of pumping and oxygenating blood. The mode of oxygenation has varied from machine to machine, but the circulation of the blood, with a few exceptions, has been carried out by some form of "tube" pump, because they are easy to sterilize. In such pumps pressure is applied externally to flexible tubing by rollers, mechanical fingers, or plattens in a sequential manner, thus ensuring a unidirectional flow without the use of valves. The output can be varied by altering the rate or degree of compression of the tubing. When run in the non-occlusive position, i.e., the walls of the tubing not in apposition, these pumps cause little haemolysis; but under these circumstances, their efficiency decreases and the output becomes dependent upon peripheral resistance.

This investigation was undertaken to compare the properties of other types of pumps, with special regard to the destruction of red blood corpuscles, ease of control of flow rate, simplicity of sterilization, and suitability for clinical practice. With this in mind, a preliminary survey was made of commercial industrial pumps having an output of up to 5 litres per minute. Seven were chosen for trial, the selection being made as representative as possible of the five basic pumping mechanisms. These mechanisms can be classified as follows (Fig. 1).

\section{TYPES OF PUMP}

A. "TuBE."-The "tube" has been already described.

B. High Speed Centrifugal.-The liquid enters at the centre of a vaned rotor and is driven by centrifugal force to an exit at the periphery. This type is usually designed to give a constant output and there are no valves.

C. Low SPEed IMPELLOR.-Similar to the centrifugal pump, but the inlet and outlet are mounted at the periphery. There are no valves and the flow is controlled by the speed of the rotation of the paddle.

D. Reciprocating.- - The volume of a chamber is increased and decreased either by a piston or by a flexible diaphragm moving in and out. The flow, which is pulsatile, is controlled by alterations in the rate or length of the stroke. In this type of pump valves are essential.

E. ARChimedean SCREw.-This classical design is best visualized from the diagram (Fig. 1 E). There are no valves and the flow rate is dependent upon the speed of the rotation of the screw.

\section{METHOD}

Fresh ox blood from the abattoir was collected into a 2-litre polythene flask containing $600 \mathrm{ml}$. of $3.8 \%$ sodium citrate. The pump under test was connected to a standard circuit consisting of a reservoir, pump, air bottle (to even out the intermittent flow of reciprocating pumps), flowmeter (rotameter metric series 14), manometer, and return tubing to the reservoir (Fig. 2). The peripheral resistance was kept at $100 \mathrm{~mm}$. Hg by a screw clip placed across the return tubing.

The circuit was first filled with normal saline and the pump output adjusted to the required flow rate. The saline was then drained off, the circuit primed with $750 \mathrm{ml}$. of the blood, and the pressure and flow rates checked. Ten-millilitre samples of blood were taken at $0,5,15,30,45$, and 60 minutes. At the end of the run the circuit was drained and cleaned by flushing with water, the pump disconnected and a previously checked pump substituted. The procedure was then repeated, using a further $750 \mathrm{ml}$. of the blood. By comparing pumps in this manner any variation in the mechanical fragility of the blood was eliminated. All tests were carried out at room temperature.

The haemolysis rate was calculated by the rise in level of plasma haemoglobin, as measured by Dacie's (1954) modification of Bing and Baker's method. Platelet counts were estimated using the direct method of Oettle and Spriggs (1951), and platelet function assessed from the change in thromboplastin generation time (Biggs and Douglas, 1953). Changes in the plasma protein fraction of the blood were investigated by electrophoresis (Flynn and de Mayo, 1951). 

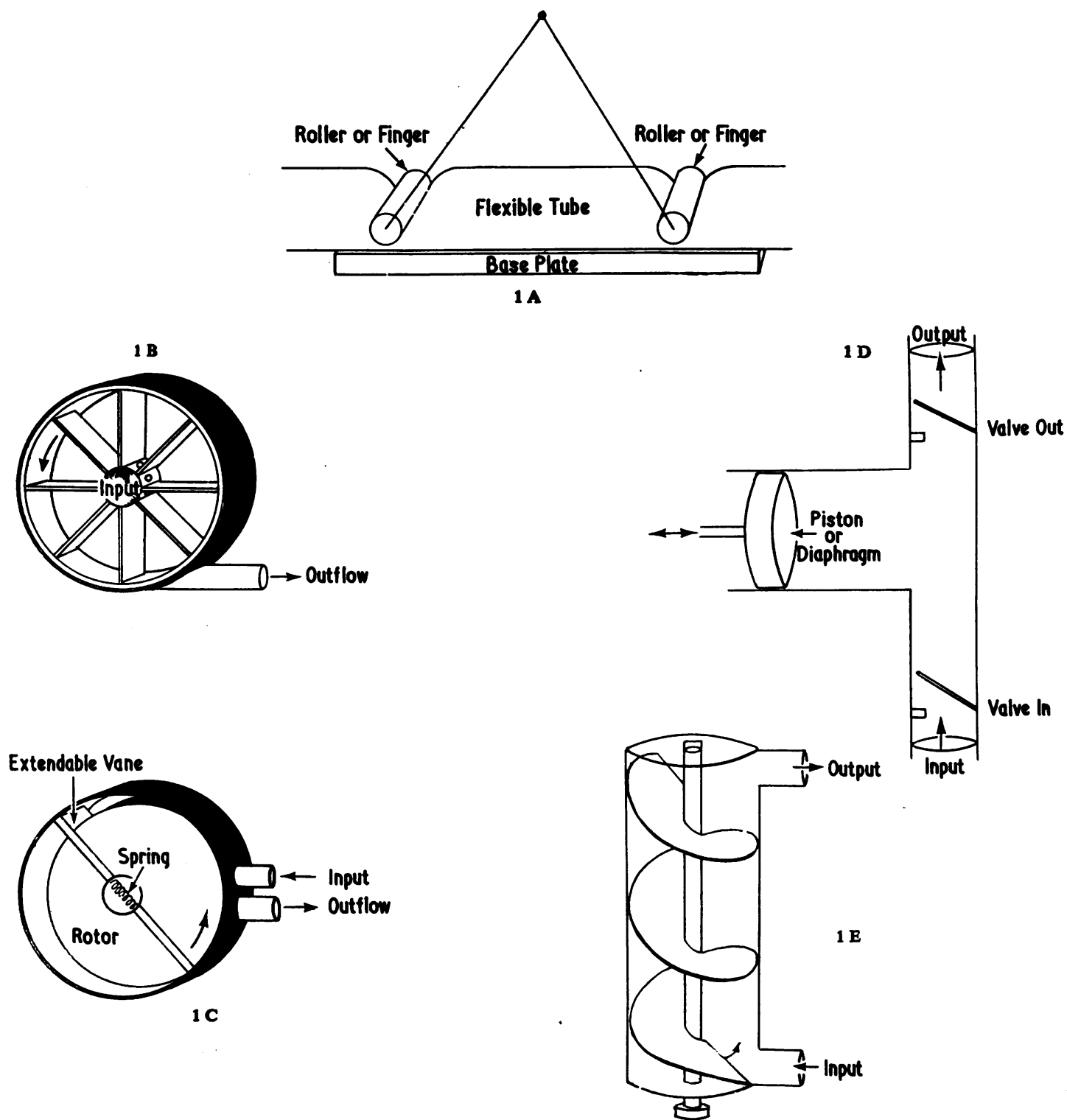

FIG. 1.-Types of pumps.

\section{RESULTS}

HAEMOLYSIS.-Table I shows the haemolysis rates of five pumps measured at a flow rate of 1 litre per minute and Table I(A) of two pumps whose flow rate could not be reduced below 10 and 3.8 litres per minute respectively. The pumps giving the lowest haemolysis, the Mono and the Candy, were further tested at a flow rate of 5 litres per minute and the results are shown in Table II.
Platelet and Plasma Protein Change.-These were measured on the same two pumps which had been investigated at higher flow rates. Observations were made at the beginning and end of one hour's run at a flow rate of 1 litre per minute. The results of platelet counts are given in Table III and showed a reduction of approximately $8 \%$. The thromboplastin generation time did not alter. There was no significant change in the plasma proteins as shown by the electrophoretic pattern (Fig. 3). 


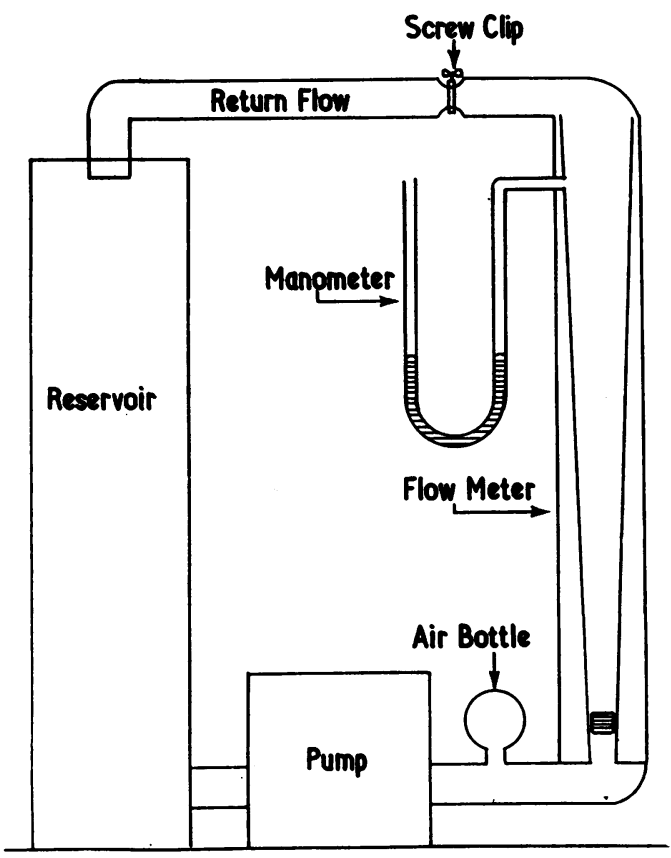

Fig. 2.-Schematic diagram of the test circuit.

TABLE 1

RESULTS AT 1 LITRE PER MINUTE

\begin{tabular}{|c|c|c|c|c|c|c|c|}
\hline \multirow[b]{2}{*}{ Type of Pump } & \multicolumn{7}{|c|}{ Plasma Hb (mg. \%) } \\
\hline & $\begin{array}{c}\mathbf{0} \\
\text { Min. }\end{array}$ & $\begin{array}{c}5 \\
\text { Min. }\end{array}$ & $\begin{array}{c}15 \\
\text { Min }\end{array}$ & $\begin{array}{c}30 \\
\text { Min. }\end{array}$ & $\begin{array}{c}45 \\
\text { Min. }\end{array}$ & $\begin{array}{c}60 \\
\text { Min. }\end{array}$ & $\begin{array}{c}\text { In- } \\
\text { crease } \\
\text { per } \\
\text { Hour }\end{array}$ \\
\hline $\begin{array}{l}\text { A. Tube } \\
\text { Sigma T-6S non-occlu- } \\
\text { sive }\end{array}$ & 16.0 & $20 \cdot 0$ & $25 \cdot 5$ & 36.8 & 46.0 & 56.5 & 40.5 \\
\hline $\begin{array}{l}\text { Sigma T.6S occlusive } \\
\text { C. Impellor } \\
\text { Norman Blackmer } \\
\text { "D" Pump }\end{array}$ & $13 \cdot 2$ & $19 \cdot 0$ & 31.6 & 46.8 & $64 \cdot 5$ & 82.5 & $69 \cdot 3$ \\
\hline $\begin{array}{l}\text { D. Reciprocating } \\
\text { Candy Major GMV/ } \\
\text { SS.28 G. }\end{array}$ & $14 \cdot 1$ & 15.0 & $17 \cdot 6$ & $21 \cdot 0$ & $23 \cdot 2$ & $26 \cdot 5$ & 12.4 \\
\hline $\begin{array}{l}\text { Candy Minor MM/SS. } \\
\text { 30 G. } \\
\text { E. Screw }\end{array}$ & $17 \cdot 8$ & 18.8 & $23 \cdot 2$ & $27 \cdot 0$ & 29.0 & $34 \cdot 0$ & $16 \cdot 2$ \\
\hline Mono SB15R5/B .. & 12.5 & $15 \cdot 5$ & $19 \cdot 5$ & 28.0 & $34 \cdot 8$ & $42 \cdot 0$ & $29 \cdot 5$ \\
\hline
\end{tabular}

TABLE I(A)

RESULTS AT OTHER FLOW RATES

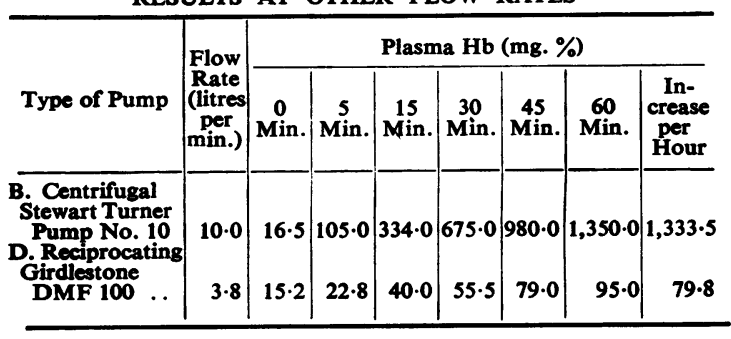

TABLE II

RESUltS AT 5 LITRES PER MINUTE

\begin{tabular}{l|r|r|r|r|r|r|r}
\hline & \multicolumn{6}{|c}{ Plasma Hb (mg. \%) } \\
\cline { 2 - 7 } Type of Pump & $\begin{array}{c}0 \\
\text { Min. }\end{array}$ & $\begin{array}{c}5 \\
\text { Min. }\end{array}$ & $\begin{array}{c}15 \\
\text { Min. }\end{array}$ & $\begin{array}{c}30 \\
\text { Min. }\end{array}$ & $\begin{array}{c}45 \\
\text { Min. }\end{array}$ & $\begin{array}{c}60 \\
\text { Min. }\end{array}$ & $\begin{array}{c}\text { In- } \\
\text { crease } \\
\text { per } \\
\text { Hour }\end{array}$ \\
\hline $\begin{array}{ll}\text { D. Reciprocating } \\
\text { Candy }\end{array}$ & 18.3 & 20.5 & 31.9 & 48.0 & 59.8 & 72.0 & 53.7 \\
$\begin{array}{l}\text { E. Screw } \\
\text { Mono.. }\end{array}$ & 10.6 & 24.2 & 53.0 & 94.0 & 135.0 & 182.0 & 171.4 \\
\hline
\end{tabular}

TABLE III

PLATELET Change

\begin{tabular}{ll|c|c|c}
\hline & \multicolumn{3}{|c}{ Platelet Counts } \\
\cline { 3 - 4 } Type of Pump & & \multicolumn{2}{|c|}{ Time } & \% Fall \\
\cline { 2 - 3 } & & 0 Min. & 60 Min. & \\
\hline $\begin{array}{l}\text { D. Reciprocating, Candy } \\
\text { E. Screw, Mono }\end{array}$ & $\ldots$ & 222,000 & 204,000 & $8 \cdot 1$ \\
\hline
\end{tabular}

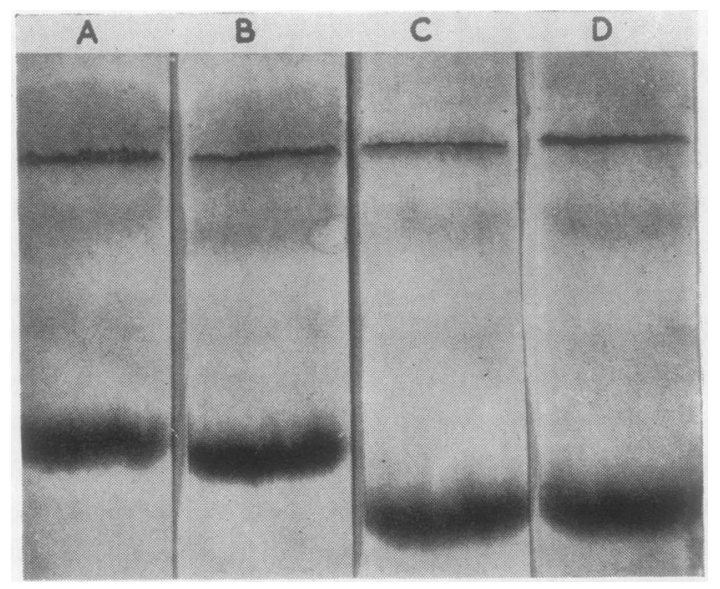

FIG. 3.-Protein paper electrophoresis. A, Initially, Mono pump. B, After one hour, Mono pump. C, Initially, Candy pump D, After one hour, Candy pump.

\section{Discussion}

A study of Table I shows that the rise in plasma haemoglobin varied from 12.4 to $69.3 \mathrm{mg}$.\% per hour with pumps running at 1 litre per minute. Set out graphically (Fig. 4), the increase was found to be linear to time. As the volume of blood in the circuit was kept constant in all the experiments, these results can be interpreted in terms of haemolysis per circuit. When two pumps were run at higher flow rates ( 5 litres per minute) it was found that the increase in plasma haemoglobin was still linear to time. Moreover, the haemolysis per circuit remained approximately 


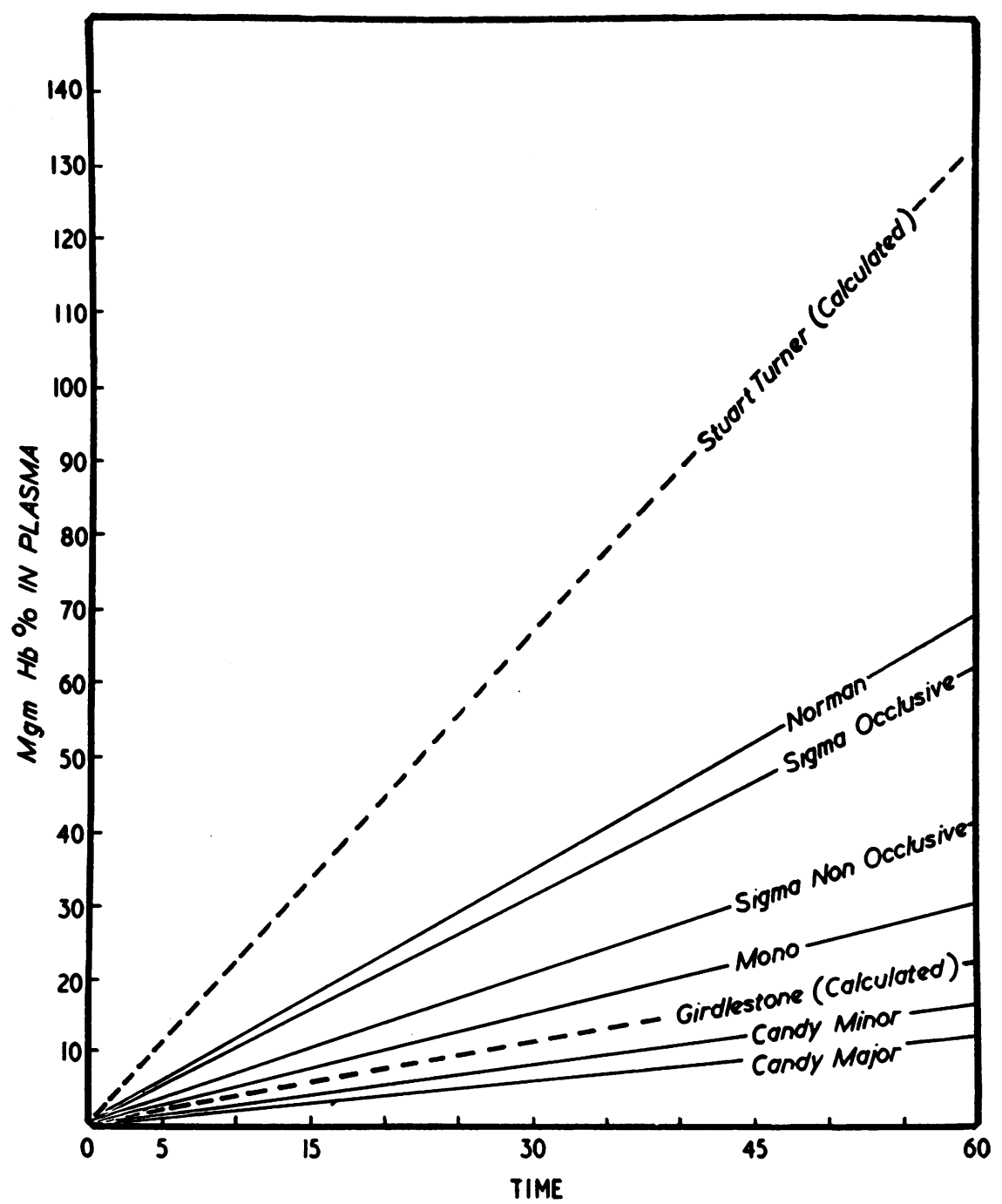

Fig. 4.-Increase of plasma $\mathrm{Hb}$ with time.

the same for each pump (Table IV), which suggests that turbulence is not a major factor in red cell destruction.

Using the criterion of haemolysis per circuit, all pumps can be compared irrespective of their flow rate (Table V). From this Table and Fig. 4 (the increases in plasma haemoglobin for the Stewart Turner and Girdlestone pumps shown in Fig. 4 were calculated from the measured haemolysis per circuit as they could not be run at low flow rates), it will be seen that the tube pump,
TABLE IV

HAEMOLYSIS PER CIRCUIT AT HIGH AND LOW FLOW RATES

\begin{tabular}{|c|c|c|c|c|}
\hline Type of Pump & $\begin{array}{c}\text { Flow Rate } \\
\text { (litres per } \\
\text { min.) }\end{array}$ & $\begin{array}{l}\text { Hourly } \\
\text { Increase in } \\
\text { Plasma Hb } \\
(\mathbf{m g} . \%)\end{array}$ & $\begin{array}{l}\text { No. of } \\
\text { Circuits }\end{array}$ & $\begin{array}{c}\text { Increase } \\
\text { in Plasma } \\
\text { Hb per } \\
\text { Circuit }\end{array}$ \\
\hline $\begin{array}{l}\text { D. Reciprocating } \\
\text { Candy .. }\end{array}$ & $\begin{array}{l}1 \\
5\end{array}$ & $\begin{array}{l}12.4 \\
53 \cdot 7\end{array}$ & $\begin{array}{r}80 \\
400\end{array}$ & $\begin{array}{l}0 \cdot 155 \\
0.134\end{array}$ \\
\hline $\begin{array}{l}\text { E. Screw } \\
\text { Mono }\end{array}$ & $\begin{array}{l}1 \\
5\end{array}$ & $\begin{array}{r}29.5 \\
171.4\end{array}$ & $\begin{array}{r}80 \\
400\end{array}$ & $\begin{array}{l}0.370 \\
0.428\end{array}$ \\
\hline
\end{tabular}


TABLE V

HAEMOLYSIS PER CIRCUIT

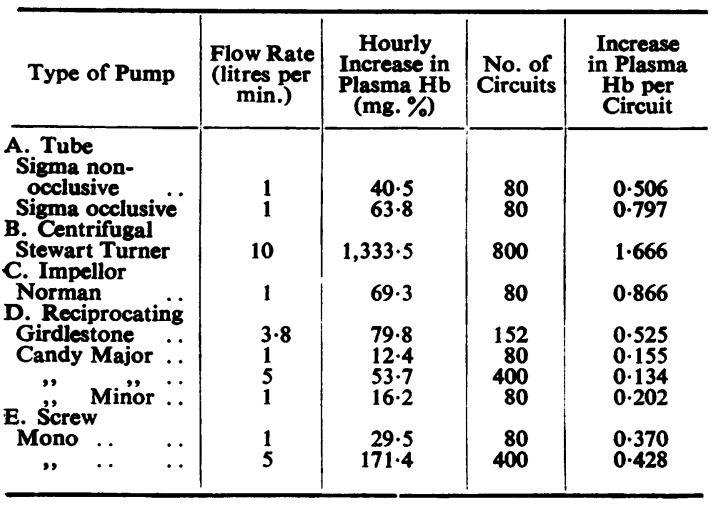

contrary to general belief, compares unfavourably with the others, higher haemolysis figures being obtained only with the Norman and Stewart Turner, both of which were designed for rapid water circulation and had rough interior surfaces. If attention had been given to improving the internal finish the haemolysis rate might have been lower. The lowest rates were obtained with reciprocating types, with spring-loaded flap valves. This is in agreement with the findings of Dennis, Karlson, Eder, Nelson, Eddy, and Sanderson (1951), who compared the DeBakey pump with a modified Dale Schuster pump.

Of those pumps with low breakdown rates, the Candy and the Mono were considered suitable for further trial for the following reasons. They were both metering pumps, i.e., they delivered a fixed volume directly related to speed or stroke, irrespective of the peripheral resistance. They could, with slight modifications, be sterilized by autoclaving, and they were of a suitable size and weight for any heart-lung machine likely to be used in an operating theatre. They were, therefore, investigated for effects on platelet and protein disturbance. These disturbances were minimal, the platelet reduction of $8 \%$ per hour being within acceptable limits and the fact that the thromboplastin generation time did not alter was an indication that the remaining platelets were functioning efficiently at the end of one hour's run. The electrophoretic pattern remained un- changed throughout with either pump, showing $\stackrel{\overrightarrow{\bar{S}}}{\overrightarrow{3}}$ that there was no significant alteration in the 0 plasma proteins.

From this investigation both the Candy and $\frac{\bar{D}}{\frac{D}{2}}$ Mono pumps would seem to be suitable for in- $\stackrel{\mathbb{Q}}{\Omega}$ corporation in a heart-lung machine, being more efficient, particularly in terms of damage to blood, $\rightarrow$ than the commonly used tube pump. Their only? individual difference is in flow pattern. The $\overrightarrow{\vec{\omega}}$ Candy has a pulsatile flow which closely mimics $\stackrel{\omega}{\circ}$ the action of the normal heart, as not only can the $\overrightarrow{\vec{x}}$ "pulse rate" be altered but also the "pulse volume." The Mono gives a continuous flow. No attempt has been made to study the relative merits $\vec{\omega}$ of such differences in flow patterns.

\section{SUMMARY}

A comparison has been made of a number of types of industrial pumps which might have appli- $\stackrel{\widehat{S}}{\supset}$ cation for extracorporeal circulation in man.

The rate of red cell destruction, platelet, and $\vec{f}$ plasma protein changes have been measured under ${ }^{\circ}$ standard conditions.

Two types of pumps, namely, reciprocating and screw, were found to be superior to the commonly used tube variety and, with slight modifications, $\stackrel{2}{\not}$ would merit trial for extracorporeal circulation in man.

We are indebted to all the members of the British Pump Manufacturers Association for their keenness and co-operation in this project, most especially the Candy Filter Company Ltd., Mono Pumps Limited, Norman Engineering Company, and Girdlestone으 Pumps Ltd. ; also to Mr. N. A. A. Myers, who, before $\ddot{x}$ his return to Australia, collected much of the infor- -0 mation about industrial pumps, and to Dr. Angus 3 . Smith for the loan of his Sigma pump.

We would like to thank Drs. J. C. W. MacFarlane 3 and R. H. Wilkinson for their work on the thromboplastin generation times and protein electrophoresis,. and our senior technician, Mr. G. Gough, for his $\frac{7}{0}$ assistance.

\section{REFERENCES}

Biggs, R., and Douglas, A. S. (1953). J. clin. Path., 6, 23.

Dacie, J. V. (1954). The Haemolytic Anaemias, Congenital and

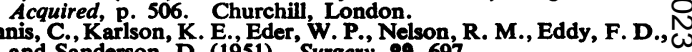
and Sanderson, D. (1951). Surgery, 29, 697.

Flynn, F. V., and Mayo, P. de (1951). Lancet, 2, 235

Flynn, F. V., and Mayo, P. de (1951). Lancet, 2, 235.

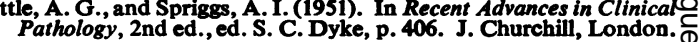

